\title{
Analisis Perhitungan, Pencatatan Dan Pelaporan Pajak Penghasilan Pasal 23 Atas Pengadaan Barang Dalam Hal Ini Jasa Penyewaan Barang Berat Pada PT.William Makmur Perkasa
}

\author{
Oleh: \\ Cicilia Tinangon \\ David Paul Elia Saerang \\ Inggriani Elim
}

\author{
Fakultas Ekonomi dan Bisnis, Jurusan Akuntansi \\ Universitas Sam Ratulangi Manado
}

\begin{abstract}
In running the government, a State must run the economy well. This affects the country for the prosperity of society development in order to achieve the objectives set by the State Act. One aspect in the implementation of the necessary development funding comes from tax revenue. The purpose of this study was to determine the mechanism of calculation, recording and reporting of Income Tax Article 23 on the procurement of goods in this respect rental services heavy loads PT.William Perkasa Makmur. The analysis method used in this research is descriptive analysis method. The results showed that as a company engaged in the field of contracting and rental of heavy equipment, PT. William Makmur Perkasa continue to provide tools that have the best quality and the weight to be able to sustain the work. The company realizes the development in this area both by the Government and private parties, seen also with the advent of the projects undertaken by the Government to prepare the facilities and infrastructure to support the development of the area, of course, which is a prerequisite for the entry of investors in investing. Laws and regulations on taxation applicable always changes the company should remain always pay attention to it. This is important so that it can determine the amount of income tax 23 in accordance with the existing rules.
\end{abstract}

Keywords: Income tax 23, Procurement of goods, Mechanism of calculation, Recording and reporting

\section{PENDAHULUAN}

Dalam menjalankan pemerintahan, suatu Negara harus menjalankan roda perekonomiannya dengan baik. Hal ini berpengaruh terhadap pembangunan Negara untuk kemakmuran masyarakatnya dalam rangka mencapai tujuan Negara yang diatur oleh UndangUndang. Salah satu aspek dalam penyelenggaraan pembangunan diperlukan dana yang berasal dari penerimaan pajak. Penerimaan dari sektor perpajakan (terdiri atas penerimaan pajak dan kepabeanan dan cukai) mendanai lebih dari 70 persen belanja Negara pada Anggaran Pendapatan dan Belanja Negara (APBN) 2013. Setiap tahun, target penerimaan dari kedua sektor ini juga selalu meningkat.

Tahun ini, Kementrian Jenderal Bea dan Cukai (DJBC) memegang peranan besar dalam upaya pencapaian target penerimaan pajak sebesar Rp. 1.042,3 triliun dan target penerimaan kepabeanan dan cukai sebesar Rp. 150,7 triliun. (sumber: Media Keuangan Vol. VIII | No. 66 / Februari 2013: 5). Target penerimaan Negara dari Direktorat Jenderal Pajak (DJP) untuk tahun 2013 sebesar Rp. 995,22 triliun, naik 19,15\% dibandingkan penerimaan pajak tahun 2012 sebesar Rp. 835,25 triliun. Namun, target pajak tersebut sebetulnya sudah direvisi dari APBN Rp. 1.042,3 triliun. Awalnya pemerintah menargetkan dapat mengumpulkan pajak di 2013 
sebesar 22,5\% lebih tinggi dari target 2012 sebesar Rp. 888,02 triliun. (sumber: Metrotvnews.com, 2013).

Salah satu jenis pajak yang ditetapkan pemerintah adalah Pajak Penghasilan yaitu pajak yang dikenakan terhdapa subjek pajak atas penghasilan yang diterima atau diperolehnya dalam tahub pajak atau dapat pula dikenakan pajak atas penghasilan dalam bagian tahun pajak. Ada beberapa jenis Pajak Penghasilan yang salah satunya adalah PPh Pasal 23 yang merupakan salah satu jenis pajak yang pelunasannya dalam tahun berjalan dipungut oleh pihak ketiga. Sebagai pemungut pajak, maka pihak ketiga tersebut dalam tahun berjalan mempunyai kewajiban untuk memotong, menyetor dan melaporkan pajak yang terutang setiap bulan atau pada masa pajak tersebut. Ada kemungkinan wajib pajak pungut keliru dalam memperhitungkan jumlah $\mathrm{PPh}$ pasal 23 yang dipungut sehingga berpengaruh terhdapa pemotongan $\mathrm{PPh}$ pasal 23 yang bersangkutan. Oleh karena itu diperlukan pemahaman yang baik terhadap tata cara pemungutan dan perhitungan PPh pasal 23 tersebut.

Setiap sektor usaha yang baik perorangan maupun yang memiliki badan hukum memiliki kewajiban untuk menyetor dan melaporkan pajak terutangnya. Salah satu contoh kegiatan badan usaha yang wajib untuk menyetor dan melaporkan pajak terutangnya seperti kegiatan usaha pengadaan barang yang dibiayai dengan APBN/APBD. Pengadaan barang dan jasa bagi pemerintah pada dasarnya adalah menyediakan atau memenuhi kebutuhan pemerintah pusat maupun daerah dalam hal institusi pemerintah baik dalam hal barang maupun jasa keahlian.

Tujuan penelitian ini untuk mengetahui mekanisme perhitungan, pencatatan dan pelaporan Pajak Penghasilan Pasal 23 atas pengadaan barang dalam hal ini jasa penyewaan barang berat pada PT.William Makmur Perkasa.

\section{TINJAUAN PUSTAKA}

Pajak mempunyai peranan yang sangat penting dalam pembangunan suatu negara karena pendapatan terbesar suatu negara berasal dari pembayaran pajak yang dilakukan masyarakat. Mardiasmo (2011:1) menyatakan bahwa Pajak adalah iuran rakyat kepada kas Negara berdasarkan undang-undang yang dapat dipaksakan dengan tiada mendapat imbalan kontraprestasi yang langsung dapat ditunjukan dan yang dapat digunakan untuk membayaran pengeluaran umum.

Akuntansi pajak penghasilan sesuai PSAK No. 46 paragraf ke-22 (Ikatan Akuntan Indonesia., Per tanggal 9 Agustus 2010) menggunakan dasar akrual. Dasar akrual dalam akuntansi pajak karena faktor kepastian peraturan pajak dan digunakannya self assessment system sebagai dasar pemungutan pajak. Dalam PSAK No. 46 paragraf kedua, edisi revisi per tanggal 9 Agustus 2010 bertujuan mengatur perlakuan akuntansi untuk Pajak Penghasilan. Cara mempertanggungjawabkan konsekuensi pajak pada periode berjalan dan periode mendatang yaitu yang dinyatakan oleh Waluyo (2009:182) sebagai berikut:

1. Nilai tercatat aset yang diakui pada neraca perusahaan atau pelunasan nilai tercatat kewajiban yang diakui pada neraca perusahaan.

2. Transaksi-transaksi atau kejadian-kejadian lain pada periode berjalan yang diakui pada laporan keuangan perusahaan. Masalah pengakuan asset atau kewajiban pada laporan keuangan diartikan bahwa perusahaan yang menyusun laporan keuangan dapat memiliki nilai tercatat pada asset atau akan melunasi nilai tercatat pada kewajiban.

Resmi Siti (2011:74) menyatakan bahwa Pajak Penghasilan (PPh) adalah pajak yang dikenakan terhadap subjek Pajak atas penghasilan yang diterima atau diperolehnya dalam satu tahun pajak. Subjek Pajak Penghasilan adalah segala sesuatu yang mempunyai potensi untuk memperoleh penghasilan dan menjadi sasaran untuk dikenakan pajak. Berdasarkan Pasal 2 ayat 1 Undang-undang No. 36 Tahun 2008, sedangkan Objek pajak penghasilan adalah penghasilan, yaitu setiap tambahan kemampuan ekonomis yang diterima atau diperoleh wajib pajak, baik 
yang berasal dari Indonesia maupun dari luar Indonesia, yang dapat dipakai untuk konsumsi atau untuk menambah kekayaan wajib pajak yang bersangkutan, dengan nama dan dalam bentuk apa pun (Resmi, Siti, 2011:79).

Pajak Penghasilan (PPh) Pasal 23 adalah pajak yang dipotong atas penghasilan yang diterima atau diperoleh Wajib Pajak dalam negeri (orang pribadi maupun badan), dan bentuk usaha tetap yang berasal dari modal, penyerahan jasa, atau penyelenggaraan kegiatan selain yang telah dipotong PPh Pasal 21. (Resmi Siti 2009:311). PPh pasal 23 terhutang atas berbagai kegiatan pemberian jasa serta sewa seperti berikut ini (Djoko Muljono 2009:167) :

1. Jasa katering

2. Jasa perawatan lingkungan (kebersihan)

3. Jasa pelaksana konstruksi

4. Jasa perancang dan pengawasan konstruksi

5. Jasa perancang dan pengawasan kontruksi

6. Jasa tenaga ahli

7. Jasa lainnya

8. Sewa angkutan darat

9. Sewa harta bergerak selain angkutan darat dan selain sewa tanah dan bangunan.

\section{METODOLOGI PENELITIAN}

\subsection{Jenis Penelitian}

Jenis penelitian yang digunakan adalah penelitian deskriptif kualitatif, yaitu berupa studi kasus dan studi pustaka. Studi kasus dilakukan pada Kantor PT. William Makmur Perkasa, sedangkan studi pustaka dilakukan dengan mengumpulkan data-data dari literatur-literatur yang relevan dengan permasalahan Pajak Penghasilan Pasal 23. Waktu penelitian mulai dilaksanakan pada bulan Februari 2015.

\subsection{Prosedur Penelitian}

Prosedur yang dilakukan dalam penelitian ini adalah:

1. Menentukan judul dan merumuskan masalah.

2. Mengumpulkan data sesuai permasalahan yang diangkat.

3. Pengumpulan data melalui wawancara terhadap pihak-pihak yang terkait serta pengambilan data-data pada Kantor PT. William Makmur Perkasa untuk mengetahui bagaimana mekanisme perhitungan dan pelaporan Pajak Penghasilan Pasal 23 atas pengadaan barang.

4. Mengolah data dan menginterprestasikan hasil pengolahan data.

5. Menarik kesimpulan dan memberikan saran yang dianggap perlu sebagai perbaikan dalam masalah yang ada.

\subsection{Metode Pengumpulan Data}

Metode yang digunakan dalam penelitian ini adalah studi lapangan, yaitu dengan datang langsung ke Dinas Pendapatan Daerah Provinsi Sulawesi Utara dan melakukan teknik pengumpulan data sebagai berikut:

1. Wawancara, dilakukan dengan wawancara secara langsung dengan pihak kantor PT. William Makmur Perkasa mengenai Pajak Penghasilan Pasal 23 atas pengadaan barang.

2. Observasi, merupakan pengumpulan data yang dilakukan dengan pengamatan langsung terhadap struktur organisasi, daftar pemungutan $\mathrm{PPh}$ pasal 23 atas pengadaan barang, buku pemungutan pajak, SSP pada PT. William Makmur Perkasa.

\section{Metode Analisis Data}

Metode analisis yang digunakan dalam penelitian ini adalah analisis deskriptif yaitu suatu metode yang dilakukan dengan cara mengumpulkan, menyajikan, serta menganalisis data sehingga diperoleh gambaran yang cukup jelas tentang masalah yang dihadapi mengenai perhitungan dan pelaporan $\mathrm{PPh}$ pasal 23 atas pengadaan barang, kemudian ditarik suatu 
kesimpulan mengenai mekanisme perhitungan dan pelaporan $\mathrm{PPh}$ pasal 23 atas pengadaan barang pada PT. William Makmur Perkasa apakah sesuai dengan Keputusan Menteri Keuangan Nomor 254/KMK.03/2001 tentang penunjukan pemungutan PPh pasal 23, sifat dan besarnya pungutan serta tata cara penyetoran dan pelaporannya sebagaimana telah diubah terakhir dengan PMK No. 08/PMK.03/2001 tentang penunjukan pemungutan PPh pasal 23, sifat dan besarnya pungutan serta tata cara penyetoran dan pelaporannya.

\section{HASIL ANALISIS DAN PEMBAHASAN \\ 4.1.Hasil Analisis}

PT. William Makmur Perkasa adalah perusahaan yang bergerak dalam usaha kontraktor dan penyewaan alat-alat berat. Perusahaan ini didirikan dengan maksud untuk mengambil peluang atas perkembangan investasi baik yang dilakukan oleh pemerintah maupun swasta. Hal ini sejalan dengan perkembangan pembangunan yang ada dewasa ini.

Usaha ini di ambil karna kontraktor-kontraktor yang ada pada waktu itu berasal dari luar daerah dan mereka hanya mempekerjakan pada subkontraktor yang ada di daerah ini. Maka pada Tahun 1998 didirikan perusahaan ini dan menempatkan dana untuk membeli alat-alat berat. Tujuan nya untuk dapat mengikuti tender yang dilakukan oleh Pemerintah maupun Swasta.

Pada penelitian ini hanya diutarakan pada kegiatan penyewaan alat berat. Sebagai perusahaan yang bergerak pada bidang kontraktor dan penyewaan alat-alat berat. Perusahaan terus berupaya menyediakan alat-alat yang mempunyai kualitas dan bobot terbaik untuk dapat menopang pekerjaan. Karena perusahaan menyadari perkembangan yang terjadi di daerah ini baik yang dilakukan Pemerintah maupun pihak swasta. Ini pula terlihat dengan munculnya proyek-proyek yang dilakukan Pemerintah dengan menyiapkan sarana dan prasarana untuk mendukung pengembangan daerah dan ini tentunya yang menjadi syarat masuknya investor dalam berinvestasi. Untuk itu Perusahan pada tahun terakhir ini telah menyediakan berbagai alat-alat untuk mengerjakan berbagai proyek. Adapun alat berat yang tersedia pada perusahaan seperti nampak pada tabel berikut:

Tabel 1.Daftar Alat-Alat Berat

\begin{tabular}{lc|}
\hline \multicolumn{1}{c}{ Jenis - Jenis Alat berat } & Jumlah Unit \\
\hline Excavator Hitachi & 10 \\
Dozer Komatsu D 85 SS & 15 \\
Vibro Volvo SD 100 & 5 \\
Loader Komatsu WA 320 & 17 \\
Grader Caterpilar 120 H & 8 \\
Dump Truck & 15 \\
\hline
\end{tabular}

Sumber : PT. William Makmur Perkasa, 2014

\section{Perhitungan Sewa Peralatan}

Bilamana pekerjaan yang berkaitan dengan proyek tidak lagi membutuhkan alat berat maka perusahaan menyewakan alat tersebut kepada kontraktor lainnya. Tujuannya adalah memanfaatkan waktu yang tidak terpakai, hal ini dilakukan karena perusahaan juga mempekerjakan tenaga kerja dengan bayaran bulanan. Penyewaan alat ini besarannya tergantung pada jenis alat dan lama sewa. Adapun jenis alat dan besaran sewa seperti nampak pada tabel di bawah ini: 
Tabel 2. Jenis Alat dan Besaran Sewa

\begin{tabular}{ll}
\multicolumn{1}{c}{ Jenis - Jenis Alat berat } & Besaran Sewa \\
\hline Excavator Hitachi & Rp. 300.000/jam \\
Dozer Komatsu D 85 SS & Rp. 550.000/jam \\
Vibro Volvo SD 100 & Rp. 250.000/jam \\
Loader Komatsu WA 320 & Rp. 500.000/jam \\
Grader Caterpilar 120 H & Rp. 3.500.000/hari \\
Dump Truck & Rp. 300.000/ret \\
\hline
\end{tabular}

Sumber : PT. William Makmur Perkasa, 2014

Pada penelitian dan pembahasan ini hanya difokuskan pada bulan Desember 2014 karena perusahaan menggunakan Tahun Kalender untuk penyusunan Laporan Keuangan. Berdasarkan hasil penelitian dan informasi yang disampaikan oleh perusahaan bahwa selama bulan Desember perusahaan telah menyewakan alat beratnya kepada pihak ketiga seperti pada tabel di bawah ini.

Tabel 3. Perhitungan Sewa Alat bulan Desember 2014

\begin{tabular}{lccc}
\hline \multicolumn{1}{c}{ Jenis - Jenis Alat berat } & $\begin{array}{c}\text { Besaran Sewa } \\
\text { Rupiah }\end{array}$ & Lama & Jumlah \\
\hline Excavator Hitachi & $300.000 /$ jam & 36 & 10.800 .000 \\
Dozer Komatsu D 85 SS & $550.000 /$ jam & 20 & 11.000 .000 \\
Vibro Volvo SD 100 & $250.000 /$ jam & 10 & 2.500 .000 \\
Loader Komatsu WA 320 & $500.000 /$ jam & 15 & 7.500 .000 \\
Grader Caterpilar 120 H & $3.500 .000 /$ hari & 7 & 24.000 .000 \\
Dump Truck & $300.000 /$ ret & 32 & 9.600 .000 \\
Total Sewa Alat & & & 65.400 .000 \\
\hline
\end{tabular}

Sumber : PT. William Makmur Perkasa, 2014

\section{Pencatatan atas Pendapatan Sewa Peralatan}

Proses pencatatan akuntansi yang dilakukan oleh perusahaan berdasarkan transaksitransaksi yang terjadi. Untuk penyewaan alat berat dasar pencatatan dan besarannya adalah berdasarkan harga dan lamanya waktu yang telah disepakati oleh pengguna alat berat.

Dasar pencatatan akuntansi sehubungan dengan penyewaan alat berat seperti nampak pada tabel diatas dan pencatatannya adalah sebagai berikut :

Kas

65.400 .000

Pendapatan Sewa Alat

Hutang PPh 23

1.282 .350

Karena penerimaan pendapatan sewa alat sudah termasuk PPh.23 maka untuk mendapatkan besarnya hutang PPh 23 adalah sebagai berikut:

$$
\frac{2}{102} \times 65.400 .000=1.282 .350
$$

Jumlah tersebut dibulatkan pada angka terdekat.

\section{Penyetoran dan Pelaporan Pajak PPh 23}

Semua pemotongan yang dilakukan oleh perusahaan sehubungan dengan usahanya dilakukan berdasarkan aturan perpajakan yang ada baik itu mekanisme perhitungan dan penyetorannya. Untuk $\mathrm{PPh} 23$ pemotongan dilakukan pada saat penerimaan sewa dan 
penyetoran dilakukan pada bulan berikut di bawah tanggal 10 bulan tersebut. PPh 23 yang terutang dicantumkan pada laporan keuangan Tahun tersebut pada Pos Hutang Lancar. Berikut ini laporan keuangan yang mencantumkan rekening Hutang PPh 23 pada Laporan Neraca seperti pada gambar berikut:

PT. William Makmur Perkasa

Laporan Neraca

Per 31 Desember 2014

\begin{tabular}{clc}
\hline AKTIVA & KEWAJIBAN DAN MODAL SAHAM \\
\hline & Kewajiban Lancar: & \\
& Hutang Dagang & $\mathrm{XX}$ \\
& Hutang PPh 23 & 1.282 .350 \\
& Hutang Lain-lain & $\mathrm{XX}$ \\
& Total Hutang Lancar & $\mathrm{XX}$ \\
\hline
\end{tabular}

Sumber: PT. William Makmur Perkasa, 2014

\subsection{PEMBAHASAN}

Perusahaan yang menjadi objek penelitian adalah perusahaan kontraktor dan sekaligus menyewa alat berat yang ada. Ini dimaksudkan untuk memanfaatkan alat yang belum di pakai pada pekerjaan yang ada. Sehingga perusahaan ini wajib memotong PPh 23 kepada pengguna alat tersebut. Penyewaan alat berat merupakan objek pajak penghasil pasal 23 dimana pemyewa harus memotong sebesar $2 \%$ dan disetorkan ke kas Negara paling lambat tanggal 10 bulan berikutnya. Besaran $2 \%$ tergatung pada jumlah yang ditetapkan oleh penyewa apakah termasuk jumlah sewa atau tidak termasuk pada jumlah sewa tersebut. Pada pembahasan ini dimaksudkan untuk mengetahui apakah proses perhitungan dan pelaporan yang berkaitan dengan sewa alat dimana menyebabkan perusahaan harus memotong pajak telah dilakukan sesuai dengan atau berdasarkan undang-undang perpajakan yang ada. Pada pembahasan ini akan dilakukan langkah-langkah sebagai berikut; perhitungan besarnya sewa alat, pencatatan atas sewa alat, penyetoran dan pelaporan $\mathrm{PPh} 23$.

Proses pencatatan akuntansi atas transaksi-transaksi yang terjadi pada berbagai unit usaha berdasarkan pada bukti-bukti yang ada. Bukti tersebut dihasilkan oleh sistem dan prosedur yang ada pada unit usaha. Sehingga informasi yang di catat benar-benar terjadi dan melibatkan berbagai fungsi yang ada. Bila memperhatikan mekanisme atau fungsi yang ada pada perusahaan seperti nampak pada gambar 4.1. di atas maka dapat dikatakan informasi yang dicatat sehubungan dengan penerimaan pendapatan sewa alat seperti nampak pada tabel 4.3.di atas dapat dikatakan telah memadai. Transaksi tersebut telah di catat berdasarkan prinsipprinsip akuntansi yang di terima umum, dimana penerimaan Kas di catat sisi Debet dan Rekening Pendapat Sewa serta Rekening Hutang PPh 23 di sisi Kredit.

Keandalan atas laporan keuangan dapat di lihat pada berbagai tahapan akuntansi yang ada. Dimana proses ini mulai dari transaksi yang terjadi. Transaksi yang terjadi seperti yang diuraikan di atas di mulai dari berbagai sistem dan prosedur yang ada. Penetapan harga, Pencatatan, Pemotongan dan Penyetoran atas PPh 23 sebagai mana yang diutarakan pada bab II terdahulu dilakukan oleh penyewa alat dan disetorkan paling lambat tanggal 10 bulan berikut. Perusahaan melakukan pemotongan $\mathrm{PPh} 23$ dan penyetoran bulan berikut dalam hal ini bulan Januari Tahun 2015 untuk pemotongan yang dilakukan bulan Desember 2014. Sehingga berdasarkan pencatatan akuntansi yang ada maka perusahaan melaporkan Hutang PPh 23 pada kelompok Hutang Lancar. Dengan demikian dapat dikatakan bahwa proses pemotongan dan pelaporan $\mathrm{PPh} 23$ oleh perusahaan dapat dikatakan sesuai dengan prinsip-prinsip akuntansi yang berlaku umum dan undang-undang perpajakan yang ada. 


\section{KESIMPULAN}

Kesimpulan dalam penelitian ini adalah:

1. Harga ditentukan oleh pihak pengguna dan penyewa sehingga proses penetapan besaran $\mathrm{PPh}$ 23 yang di potong oleh Penyewa telah sesuai dengan aturan yang ada.

2. Proses pencatatan akuntansi yang dilakukan perusahaan sehubungan dengan transaksi yang menyebabkan timbulnya $\mathrm{PPh} 23$ telah memadai dan sesuai dengan prinsip-prinsip akuntansi yang berlaku umum dan undang-undang perpajakan yang berlaku.

3. Perusahaan melakukan penyetoran atas pemotongan $\mathrm{PPh} 23$ setiap tanggal 10 pada bulan berikutnya atau sebelumnya tergantung pada mana tanggal tersebut merupakan hari kerja. Dan ini sesuai dengan aturan perpajakan yang ditetapkan oleh pemerintah.

Saran dalam penelitian ini adalah:

1. Mengingat peraturan perundangan-undangan tentang perpajakan yang berlaku selalu terjadi perubahan maka hendaknya perusahaan tetap selalu memperhatikan hal tersebut. Ini penting sehingga dapat menentukan besaran PPh 23 yang sesuai dengan aturan yang ada.

\section{DAFTAR PUSTAKA}

Ikatan Akuntansi Indonesia., Per tanggal 9 Agustus (2010), "Standar Akuntansi Keuangan"., Salemba Empat.

Mardiasmo. 2011. Perpajakan. Edisi Revisi (2011), ANDI, Yogyakarta.

Media Keuangan., Vol. VIII | No. 66 / Februari (2013). Sektor Perpajakan Yang Menjadi Andalan.

Metrotvnews.com., (2013). Penerimaan Pajak., http://www.metrotvnews.com. Diakses pada 6 Januari, 2014.

Muljono, Djoko. (2009). Akuntansi Sektor Publik. ANDI, Yogyakarta.

Pemerintah Provinsi Sulawesi Utara. Keputusan Menteri Keuangan No. 254/KMK.03/2001, Tentang penunjukan pemungutan PPh pasal 23, Jakarta.

Pemerintah Republik Indonesia. PMK No. 08/PMK.03/2001, Tentang penunjukan pemungutan $\mathrm{PPh}$ pasal 2, Jakarta.

Resmi, S., (2011). Perpajakan Teori Dan Kasus, Salemba Empat, Jakarta.

Waluyo. (2009). Akuntansi Pajak. Salemba Empat, Jakarta. 